\title{
Slovenia's Foreign Policy Opportunities and Constraints: The Analysis of an Interplay of Foreign Policy Environments
}

Ana Bojinović Fenko, Zlatko Šabič

\section{Abstract}

The article focuses on the interconnectedness of foreign policy environments to explain Slovenia's opportunities and constraints for foreign policy action. During the period of pre-independence para-diplomacy, the building of an internal and external domestic environment successfully turned constraints (no international recognition) into opportunities (applying for membership of European and global intergovernmental organizations). In the second period - post-recognition - considering the absence of a strategic foreign policy document, the Slovenian internal foreign policy environment became a major constraint to seize foreign environment opportunities. This affected Slovenia's accomplishments, notably after NATO and EU memberships were achieved in 2004. Although the Slovenian internal environment matured during the following period to adopt, in 2015, a comprehensive foreign policy strategy the recent turn in world politics (especially the European financial and economic crisis and the migration crisis) created for the first time a foreign environment for Slovenia that offered many fewer opportunities and far more constraints.

KEY WORDS:

foreign policy, foreign policy environments, opportunities, constraints, Slovenia 
Slovenian foreign policy has received a lot of attention in literature. Studies provide theoretical and empirical evidence of various aspects of foreign policy analysis - for example, the organization and conduct of the foreign policy process and its individual instruments, mainly diplomacy (Brglez 1996; Udovič and Brglez 2011; Jazbec 2012), Europeanization of foreign policy (Kajnč 2011; Šabič and Bunič 2013; Bojinović Fenko and Lovec 2015), analyses of foreign policy content (decisions) (Bojinović 2005), and strategy in bilateral (neighbouring), regional (European) and relevant global issues (Bučar 1994, 1995; Bojinović Fenko and Požgan 2014; Bojinović Fenko and Šabič 2014). The least systematically researched area remains the foreign policy environment. So far, it has been addressed mostly through the prisms of 'smallness' and the 'youth' of the Slovenian state.' Consequently, there has been limited research around the presupposition that — like for all small states — the foreign environment in terms of limitations from the international system automatically prevails by decisively determining constraints for Slovenian foreign policy (Hey 2003). In this respect, we propose to broaden the research agenda by focusing on the interplay between foreign and domestic foreign policy environments. To do so, we first provide a definition of the foreign policy environment. The term is widely used in foreign policy analysis and rests on two different classifications: factor analysis of the internal-external foreign policy environment (Hill 2016) and the levels of analysis of the domesticforeign dichotomy of the foreign policy environment (Russett and Starr 1981; Kinsella, Russett and Starr 2013; Hudson 2014). This conceptualization reveals how foreign policy substance and the foreign policy making process are influenced by: a) the internal foreign policy environment; b) the external domestic foreign policy environment, defined mostly as the statebuilding environment; and c) the external foreign policy environment. The research question pursued here is how these three types of foreign policy environment influence foreign policy, whereby the term 'influence' means the extent of opportunities or constraints for foreign policy action. We assume that foreign policy is a continuous process; hence an additional question that we ask is how feedback on foreign policy actions (from the

1 A notable exception is the investigation of the geographical proximity and historical context of Slovenia in relation to 
external foreign environment) affects the domestic external and internal environments, either through self-perception or via policy-making.

The structure of the article is as follows. We first conceptualize the foreign policy environment and state building, focusing on their interplay. We then look at opportunities and constraints for taking foreign policy action. We do this by dividing the analysis into three time periods; pre-independence paradiplomacy until 1992; the consolidation of the state until 2004 membership of Euro-Atlantic integrations; and the 'mature statehood' period, in which Slovenia's foreign policy orientation is challenged by international crises which follow one after the other since the financial crisis in 2007-2008. Methodologically, the article departs from understanding foreign policy as a policy (in terms of the content of decisions) and as a policy-making process (Carlsnaes 2012), thereby employing social constructivist epistemological grounds of constant interplay between the structure (the foreign policy environment) and the actors (decisionmakers). The three-period historical analysis focuses on general normative foreign policy positions in strategic documents (self-perception and internal environment) and on selected foreign policy situations leading to concrete foreign policy decisions by Slovenian decision-makers.

\section{Foreign policy environments as sources of opportunities and constraints for action}

There are two different but complementary approaches to states' foreign policy environment. The internal-external divide follows Hill's conceptualization (2016: 176), where the internal environment corresponds to "the social and political process by which the actor comes to its choices" (Hill 2016: 183), meaning factors and actors directly involved in the foreign policy process. This environment thus includes decision-makers (in terms of their individual characteristics and their roles) and rules and norms in foreign policy-making (Kinsella, Russett and Starr 2013: 13-15). The external foreign policy environment, for its part, includes material and semi-material factors of the state and its society, 
such as demography, culture and image, including geopolitical and historical self-perception and consequently recognition of the state (Hill 2016: 176-184), and factors of international political interdependence - international governmental organizations, transnational processes, international law, foreign policies of other states and the nature and the position of the state in the international system. Kinsella, Russett and Starr (2013: Chapter 1), however, use the concept of levels of analysis to analyse the foreign policy environment. Levels of analysis are defined as "points on an ordered scale of size and complexity. These levels include units whose behaviour we attempt to describe, predict or explain, as well as units whose impact on individual decision-makers we examine" (Russett and Starr 1996: 11). The earlier approach, which used six levels of analysis (Russett and Starr 1996: 11), ${ }^{2}$ has been narrowed down to three (Kinsella, Russett and Starr 2013: Chapter 1). These are decision-makers and domestic society as the domestic environment levels of analysis, and global society as the foreign environment. External material and semi-material factors directly correspond to the domestic society level of analysis, whereas international political interdependence factors equal the global society level of analysis.

Figure 1: Interplay of external (domestic and foreign) and internal foreign policy environments

ENVIRONMENT Levels of analysis

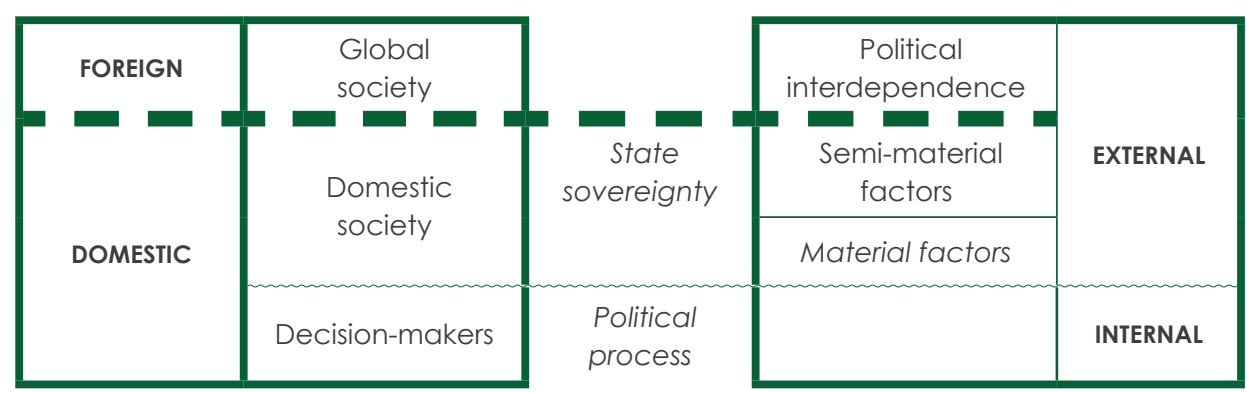

Source: Authors' own illustration based on Kinsella et al. (2013) and Hill (2016)

In sum (Figure 1), foreign policy substance and policy-making are influenced by: a) the internal foreign policy environment and, within that, by 'decision-makers'; b) external semi-material factors, equalling domestic society and government levels of analysis; and c) international interdependence or the global society level of analysis as the external

2 The previous six levels were individual, role, government, society, relations and international system (Russett and Starr 1996). 
foreign environment. The environments enable foreign policy action by offering incentives and stimulative influence (i.e. opportunities) and/ or constrain action due to negative influences preventing realization of some choices. In the following sections, we will elaborate on this conceptualization by looking at how various types of the foreign policy environment influence foreign policy-making in terms of opportunities and constraints.

\section{Pre-independence paradiplomacy: from the 1970s until international recognition in 1992}

As a Socialist Republic, paradiplomacy was used by Slovenia after the 1970s. Defined essentially as "the diplomatic practices, the international activities or the foreign policies of sub-state political entities" (Duran 2016: 1), paradiplomacy has also been interpreted as "an instance of diplomatic mediation of separation or estrangement [...] striking a middle-ground between the realist power play and the humanist need to connect and to engage with others" (Duran 2016: 4-5). As a former Yugoslav republic, Slovenia resorted to paradiplomacy to connect and engage internationally. During the break-up of Yugoslavia, Slovenian paradiplomacy took on an entirely new meaning: it was used as a tool to promote and achieve independence. In this section, we look at internal, external domestic and external foreign factors which influenced Slovenian foreign policy making at the time when Slovenia was still one of the six Yugoslav republics.

The 1974 Yugoslav Constitution (Art. 271) allowed the constituent republics to exercise their individual external relations, primarily in the fields of trade, culture, science and sports. These activities were limited to what is conceptually referred to as 'external relations' rather than 'foreign policy' (Hill 2016: 6); the Constitution did not allow the republics to conduct independent foreign policies (Art. 281: pt. 7). Whatever their own international activities, they had to be in conformity with the principles of the federal foreign policy (Yugoslav Constitution: Fundamental Principles 
pt. VII). In this respect, the normative basis of Slovenian paradiplomacy after 1975 was of a general collaborative nature and not part of a political programme with specific foreign policy content. The internal foreign policy environment in use was the Secretariat (renamed the Committee in 1980) for international cooperation of the Socialist Republic of Slovenia. It was established in 1975, and was in operation until May 1990 when, under the newly elected democratic Slovenian government, it was transformed into a de facto foreign ministry (Jazbec 2011: 114). The other important institution at the federal republic level was the Institute for International Scientific and Technical Cooperation. Both institutions were organs of the Slovenian Executive Council, the highest executive body in the Socialist Republic of Slovenia. In addition, some non-state institutions such as the Slovenian Chamber of Commerce, the Research Centre for Cooperation with Developing Countries, numerous big Slovenian companies with their foreign representations, city-to-city international contacts, international connections from university and academia contributed to what Jazbec (2011: 114-116) has called a "pre-state diplomacy". ${ }^{3}$ The internationalization of Slovenian business was particularly important. The introduction of the so-called Yugoslav "policy of open borders" in the 1970s allowed for economic liberalization (Boeckh 2014: 35) and enabled Slovenian companies to trade predominantly with Western European countries and attract foreign investments. As it later turned out, the infrastructure supporting business ties played an important role in the foreign external environment in which Slovenia needed to act to advocate for, and eventually secure, its international recognition. Last but not least, ties and collaborations should also be mentioned, with political movements such as the League of Communists, the Association of Socialist Youth and other youth organizations, Second World War veterans, trade unions and the Socialist International. Slovenian minorities, migrant workers and diaspora also played their part. Finally, various instruments for international cooperation were at the disposal of some of the aforementioned institutions, such as agreements, visits, declarations, publications, mixed commissions (e.g. with Bavaria and Carinthia), student exchange programmes and other exchanges at bilateral and

3 These paradiplomatic links had not been applied for the pursuit of foreign policy goals prior to late 1980s. It was only when the Slovenian political leadership started to develop designs for independence that all available capabilities were employed (Jazbec 2011). 
multilateral level (Boeckh 2014). ${ }^{4}$ Jazbec $(2011: 118)$ has pointed out that non-governmental paradiplomacy came to the fore only in the mid-1980s when these actors actively participated in the promotion of Slovenian democratization. This, in Duran's terms (2016: 4), can be understood as a turning point of "connecting to engage with others".

Some of the central values on which the state based its foreign policy activities derived from the nature of the domestic democratization movement. For the latter, it was essential to assure the legality of action, otherwise infringement of the Yugoslav constitution would have given the federal government and the Yugoslav Army an opportunity to legally intervene in Slovenia (Bučar 2014). Since the federal and international legal principles were the main constraints for Slovenian foreign policy action towards independence, the politicians decided to respect them and act where they were "allowed": they kept changing the Slovenian constitution and, via paradiplomacy, called upon the legitimacy of its "foreign policy" decision. Thus, it was imperative 1) to hold a plebiscite before declaring independence and 2) to respect the federal constitution with reference to the de facto implementation of independence (Bučar 2014: 205). ${ }^{5}$ The crucial factor for foreign policy action was thus the selfperception of the society and political groupings to respect the rule of (international) law in order to construct the state as a proper democracy.

The centrality of a (proper) democracy norm is directly traceable to the official documents of Slovenia, not only to the Slovenian Constitution (adopted in June 1991) but also to those related to foreign policy. The Slovenian Foreign Policy Strategy was adopted by the Slovenian National Assembly in March 1991, even before the Constitution was voted upon and brought into force. It set the foundations for a normative and substantive framework of Slovenian foreign policy. In that document, Slovenia naturally identified survival and operational capacity as primary foreign policy goals. During that time, Slovenian foreign policy-makers operated under the assumption that socialist Yugoslavia would dissolve peacefully

4 A good example of a platform that Slovenia used for developing closer ties with neighbouring countries from the West was the Alps-Adria Working Group, established in 1978. The group consisted of regional authorities from former Yugoslavia (besides Slovenia, Croatia was also a member), Italy and Austria (Klabjan 2013).

5 There are several examples of action upon such a normative ground: a constructive role of the existing Slovenian authorities prior to democratic elections in April 1990, which served as a mediator between the Slovene public and the federal authorities; after democratic elections, inclusion of the Communist Party as an opposition in the reformed democratic political system; setting a qualified majority for plebiscite results to be legitimate; and numerous amendments to the Slovenian constitution so as not to overstep the federal one (Bučar 2014: 204-209). 
(Slovenian Foreign Policy Strategy 1991: Title 2). That assumption was proved wrong, and Slovenia had to fight its way towards independence. It entered the war against the Yugoslav army (Jugoslovenska Narodna Armija: JNA). The war that Slovenia won lasted ten days (27 June - 6 July 1991). During that period, the normative ground of state building continued to be actively pursued. The most notable example was the treatment of soldiers of the defeated JNA. On 29 June 1991, the Slovenian Secretariat for Internal Affairs dispatched detailed information to all police stations in Slovenia about the legal rights of soldiers and measures to guarantee their safety. Provisions of the Geneva Convention and cooperation with the Slovenian Red Cross, which detached itself from the Yugoslav Red Cross, were particularly taken into consideration (Bojinović Fenko and Šabič 2014: 49). Another example to illustrate the same point is related to succession issues, which later became one of the most challenging for all the former Yugoslav republics. Milan Jazbec, a Slovenian diplomat who in 1991 held a post in the Yugoslav consulate in Klagenfurt, Austria, recalls that after the Slovenian declaration of independence, the Yugoslav government adopted the decision to close the consulate. The main reason for that decision appeared to be the fear of the government in Belgrade that Slovenia would seize the consulate building. However, the Slovenian government decided not to pursue that option. Rather, it declared that it would "act in accordance with international law" (Jazbec 2012). Finally, strong internal support for principles outlined in the Helsinki Final Act of 1975 (the so-called Decalogue) is also worth mentioning. The Final Act was translated into the Slovenian language soon after its signature (Jazbec 2011: 115).

The 'othering' of Yugoslavia based on developing its own identity, closer to Western democratic values, remained at the core of Slovenian advocacy for its independence after the War. Opposing the dominant discourse of the federal Yugoslav authorities, Slovenia consolidated its identity around the will to implement democratic principles, respect for human rights and international law, hoping that such a self-identification would help it be perceived as a legitimate actor in the fast-restructuring of the post-Cold War international arena. These core values were included in the Constitution of Slovenia - e.g. the respect of human rights and fundamental freedoms (Preamble, Arts. 3, 5, entire Title II, Arts. 14-65, Art. 159), of the rights of national minorities (Art. 5), the rights of foreigners (Art. 
13), of foreign workers (Art. 79), the property-acquisition rights of foreigners (Art. 68), the principle of self-determination of peoples (Preamble, Art. 3a), of democracy (Arts. 1, 3, 3a), the rule of law (Arts. 2, 3a), of social welfare (Art. 2), of territorial integrity (Art. 4), the principles of secularism, freedom and equality of religion(s) (Art.7), the subjection of national laws to general principles of international law and to binding international treaties (Arts. 8: 153), the declaration of war and state of emergency only by the National Assembly (Art. 92), and the building of national defence on the principle of the "peaceful policy and culture of peace", the oversight of which is conducted by the National Assembly (Art. 124).

In terms of more specific goals of Slovenian foreign policy in the wake of declared independence, Slovenia had two main areas of cooperation in sight, namely to pursue the "best possible relations with the republics [...] of Yugoslavia because of economic and many other reasons" (Slovenian Foreign Policy Strategy 1991: Title III C) and because of earlier experience and ties with Western economies, especially with Austria and Italy, Slovenians opted to take part in regional integration processes, particularly in the framework of the European Community (EC). The EC already had a visible presence in Slovenia due to the mediation role of the Ministerial Troika, who brokered a ceasefire between Slovenia and Yugoslavia at the Brioni (Croatia) meeting on 7 July 1991 (Rupel 1996: 192193). The "strategic goal of pursuing EC membership" was identified by Slovenia as early as March 1991 (Slovenian Foreign Policy Strategy 1991: Title V), whereby membership of other (trans)European organizations, such as the OSCE (Organization for Security and Cooperation in Europe) or the Council of Europe, was seen as strategic in the sense of clearing the path to the desired goal. ${ }^{7}$

The second important element of the internal foreign policy environment was the construction of the foreign policy system in terms of its institutions (the Ministry of Foreign Affairs, Foreign Service and diplomatic missions) and processes (Foreign Policy Act). This was the first and very challenging task

6 For a detailed analysis of Slovenian external domestic environment linkages to Western European flows (history, culture, trade) as an element of a cost-benefit analysis for pro-European integration, see Bojinović Fenko and Svetličič (2017).

7 For example, membership of the Council of Europe is a de facto mandatory requirement for any EC/EU candidate, to prove its ability to implement basic human rights standards according to the Copenhagen Criteria. In its Bulgaria Opinion from July 1997, the Commission elaborated on these criteria by underscoring that any state wishing to join the EU must first ratify the European Convention on Human Rights and Fundamental Freedoms (Commission 1997). The Convention, of course, is the main pillar of the Council of Europe's law, and every member has signed and ratified it. 
for the (not yet) independent Slovenia. Slovenia had several experienced diplomats who served in the Yugoslav Foreign Service, but an almost non-existent infrastructure. Most Yugoslav foreign policy was conducted from Belgrade. Many Slovenians who worked on foreign policy issues in the federal administration received their education or training in the Yugoslav capital. Slovenian authorities began to work on their diplomatic networks. This task was set forth in the aforementioned Slovenian Foreign Policy Strategy (1991). The document (Title 5) provided for a stronger role for a plenipotentiary of the Executive Council of the Slovenian National Assembly in Slovenia's conduct of its foreign affairs. From August 1990 until January 1991, these plenipotentiaries were sent to capitals such as Vienna, Washington, Brussels, Prague, Luxembourg, Rome, Vatican and Abidjan (Slovenian Foreign Policy Strategy 1991). The document also provided for the establishment of Slovenian representations abroad, stating that "a general principle [...] for their operation [...] is equal to formation of diplomatic representations" (Slovenian Foreign Policy Strategy 1991). The forms of these paradiplomatic representations were (Slovenian Foreign Policy Strategy 1991):

- diplomatic-consular representations and diplomatic missions with other states;

- representatives with the role and status of honorary consuls;

- common representation with the Ljubljanska banka (a state-owned bank) or other Slovenian companies abroad;

- representation of Slovenian national interests through third states (those that would recognize Slovenian independence); and

- representations together with other Yugoslav republics on the basis of a provisional agreement of common Foreign Service, where a Slovenian representative would be the Head of Slovenian representation within a common Yugoslav representation.

These plans were outlined to create a proper diplomatic and consular network after Slovenia reached international recognition. It was estimated that about 35 to 40 diplomatic-consular representations should be established worldwide (Slovenian Foreign Policy Strategy 1991). 
During the 1991 War, the military forces and diplomatic service were filled with individuals who withdrew from the JNA's command and with Slovenian diplomats stationed in Belgrade and in the Yugoslav diplomatic service. A large majority of the latter supported the goals of the Slovenian political leadership for independence and actively engaged themselves in achieving Slovenia's international recognition (Rahten 2011: 664-665). Repatriation of the Slovenian diplomats and employees working for the federal Ministry of Foreign Affairs was identified as a top priority of the state during the "transformation of powers" in the process of Yugoslav dissolution/Slovenian independence (Slovenian Foreign Policy Strategy 1991: Title 1). The domestic and foreign external environment allowed enough flexibility for this kind of action. The Yugoslav Constitution, laws and diplomatic practice provided that, for better relations with national minorities, the consular staff in neighbouring states should be of the nationality of the neighbouring federal republic (e.g. Slovenians as consuls in Klagenfurt and Trieste, Italy). The same applied for migration workers (e.g. Slovenians as consuls in Germany and in Cleveland, USA) (Jazbec 2011: 116).

The external domestic environment was identified as insufficiently developed for independent statehood, as the existing system of governance in Slovenia did not have the authority and appropriate organizational structures in essential areas of independent statehood: foreign affairs, finance, taxation, a customs system and the military (Bučar 2014: 208-209). The build-up of the structures was enabled by the Slovenian external domestic environment. Slovenia needed to demonstrate very quickly that it was able not only to establish and sustain border control in particular (in terms of military security and with respect to control of trade flows), but also to keep up democratic standards as referred to above (Bučar 2014: 210).

In terms of the external foreign environment, the factors that played a considerable role in Slovenia's effort to become an independent state ${ }^{8}$ are connected both with the crumbling of Yugoslavia and international circumstances at the time. In the former Yugoslavia, the Croatian decision to follow along the Slovenian independence claims and the empty Federal

8 Note that here we refer to Slovenian territory as a domestic environment even though it was not yet a separate state entity at the time. 
Presidency seat from mid-May 1991 was important. The non-occupied position of a Chairman of the Presidium of the Socialist Federal Republic of Yugoslavia added to the favourable political environment for making bold decisions, because the Yugoslav Army had no supreme commander (Bučar 2014: 209). At the international level, the positions of European, American and non-aligned states were not encouraging. These states had strong reservations after the Slovenian plebiscite and the declaration of independence. They accepted the possibility of a reform based on a consensus of constitutive republics, but clearly demanded that Yugoslavia remain one state. It became possible for Slovenia to pursue independence only when this conservative and in fact non-realistic view was confronted with radically changed international political circumstances which led to the break-up of multinational states. That, in turn, made room for smaller states to pursue their own interests (Bučar 2014: 214-215).9

\section{Foreign policy consolidation until 2004 membership of Euro-Atlantic organizations}

As the independence movements in Slovenia and Croatia inflamed the former Yugoslavia, which resulted in wars in Croatia and Bosnia, Slovenia steered away from its original orientation to sustain friendly and cooperative relations with former Yugoslav republics. The war made that impossible. Slovenia developed a separate discourse, which focused on differences between Slovenia and the rest of Yugoslavia, not to mention the Balkan region in general. The 'away from the Balkans' approach began to dominate discourse in both (public) diplomacy as well as domestically.

9 It is worth noting that the breakup of Yugoslavia challenged an important international norm, the principle of the right of self-determination, which was introduced in the Helsinki Final Act of 1975. Yet one needs to recall also the conflicting nature of the Helsinki principles because they also include the principle of preserving territorial integrity of states. To square the circle, "the Europeans chose to adapt their norms to their preferences and apply both principles to the federal republics as if they already were States and bearers of national sovereignty and as if international law did not oblige them to apply /these two principles/ to the Yugoslav state, its entire population and its external borders" (Woodward 1996 cited in Roberts 2016: 12). Roberts (2016: 12-15) has noted in his recent book Conversations with Milošević that such change of course was positive for Slovenia but detrimental to some other Yugoslav republics. He sees this as a shortcoming of European foreign policy which originated from prioritizing maintenance of unity among European Community member states at the expense of a long-term vision for all Yugoslav nations' future. 
The internal environment of foreign policy during this period prioritized the consolidation of the foreign policy system at the expense of substantive strategic orientation. There was no foreign policy strategic document officially endorsed until 1999. The most important element of selfidentification was democracy - respect of human rights, respect of the international law triangle and dissociation of the state from geographical proximity and the historical context of the Balkans (Bojinović 2005). In this context, the 'away from the Balkans' approach was pursued in order to associate Slovenia with Western democracies' form of international cooperation, proving Slovenia was a democratic country which did not belong to the war-waging region (Bojinović Fenko and Požgan 2014: 5962). The first example of the Slovenian 'new approach' was the rejection of participation in the South East Europe Cooperation Initiative (SECI), launched in 1996 (Bojinović 2005: 21). Seeking an alternative way to establish itself, Slovenia looked elsewhere, primarily to Central Europe. In the early 1990s, Slovenia joined the Central European Initiative, became a member of the Central European Free Trade Agreement and entered into a dialogue with the Višegrád Group (Bučar 1994). Another, albeit comparatively less advocated, alternative was the Mediterranean. In the context of preparations for the Euro-Mediterranean Partnership (EMP), Slovenia began to promote itself as the most Mediterranean among the Central European member states and as the most central European among the Mediterranean ones (Bojinović Fenko 2010: 85). However, those attempts did not result in the desired outcomes. Slovenia remained at the door of the Višegrád Group, having the status of an observer. It stayed outside the EMP as well. The limitations with respect to these two foreign policy 'slippages' originated from constraints from the external foreign policy environment. ${ }^{10}$

At the global level, the record is a mixed one. Some foreign policy decisions arguably increased Slovenia's international visibility. In 1992, Slovenia became a member of the United Nations. It presented a successful candidacy for the UN Security Council (UNSC) non-permanent seat (serving in the UNSC from 1998 to 1999). Unfortunately, Slovenia could not escape some negative global public image. The most painful

10 At that time, the EMP was pursued entirely with the instrumental purpose of joining any Western-led organization. Since the European Union had restricted the EMP to Mediterranean states of Southern Europe and North Africa and tried to manage the post-Yugoslav states via post-conflict stabilization policy, Slovenia fell short of EMP participation (Bojinović Fenko 2010: 85). 
experience in this respect took place in 1998, when Slovenia withdrew from the New Agenda Coalition (NAC), the group it helped to establish, and which advocated nuclear disarmament and non-proliferation. ${ }^{11}$ It also abandoned cooperation within the Human Security Network. ${ }^{12}$ In the same year, the government initiated establishment of the International Trust Fund (ITF) for Demining and Mine Victim Assistance in Bosnia and Herzegovina. The ITF later expanded its geographical scope to the Middle East, the South Caucasus, Latin America, North and West Africa, transforming it into one of the main actors of humanitarian demining activity worldwide (Bojinović Fenko and Požgan 2014: 60-61). These positive international engagements were seen among policy-makers as proof that Slovenia was "a reliable and a constructive partner in most important multilateral organizations [...] able to conduct most responsible political functions with credibility and success" (Rupel et al. 2000: 7).

With respect to the external domestic environment, the Slovenian 'away from the Balkans' approach gradually changed into a more inclusive (creative) way of thinking about that region; but the path to get there had many turns. For starters, an independent Slovenia wasted no time severing ties with the Non-Aligned Movement (NAM). At first sight, that seemed a logical move, since there was not much sympathy among non-aligned countries when Slovenia separated from Yugoslavia. However, the NAM at that time was still an important global player. One should also recall that the Movement was instrumental in making and sustaining Yugoslavia as a credible foreign policy actor (Boeckh 2014). This helps explain why other former Yugoslav republics were more careful in this regard. ${ }^{13}$ During the mid-1990s, not only the Balkans were far away from Slovenian sight: as membership of the European Union (EU) and NATO evidently became the primary foreign policy goals, Slovenia was highly engaged in a two-level game with the EU in terms of bilateral conditioning of the EU accession by Italy and Austria (Šabič 2002). The topics on the agenda were foreigners' rights for property acquisition, the status and rights of minorities, and denationalization (Bojinović Fenko and Urlić 2015). Additionally, a

11 The main reason for that was the 'conflict of interest'. Slovenia entered the NAC as an applicant for membership in NATO. It was subsequently 'reminded' by an influential NATO member state that several NATO members actually do have nuclear weapons, and that therefore Slovenia's application to become a NATO member was incompatible with NAC membership.

12 In fairness, this happened mainly due to limited financial and human resources.

13 For example, Croatia, which together with Slovenia was the first to leave Yugoslavia, kept its ties with the NAM (Bojinović Fenko and Šabič 2014: 53). 
domestic critical cost-benefit assessment of potential membership was largely disregarded and positive aspects of Euro-Atlantic integration were hailed by domestic political elites and consequently the public, with the minor exception of a few open academic debates (Bojinović Fenko and Svetličič 2017). The 'othering' of the (war-waging) Balkans and Yugoslav foreign policy accompanied by top-down Europeanization concerning core EU principles and values was the driver of Slovenian state foreign policy-making in the period of 1992-1998. Ironically, the very same EuroAtlantic external foreign policy environment to which Slovenia wanted to get closer by abandoning its Balkan identity and connections pushed Slovenia to completely change this and reorient its foreign policy 'back to the (Western) Balkans' in 1998. In that year, in the context of accession talks with Slovenia, the EU demanded that Slovenia take an active role in South-East European (SEE) post-conflict cooperation schemes. Slovenia was extremely reluctant to do so as that compromised its effort to build an 'away from the Balkans' foreign policy profile. Importantly, in the domestic external environment, anti-Balkan sentiments were widespread. These developments were rather worrying for the then Slovenian government, which feared that domestic opposition parties would interpret Slovenian engagement in SEE as a reestablishment of the former Yugoslavia (Bojinović 2005: 21). In truth, such critical voices were understandable, because the public could not see the direction in which Slovenia wanted to go with its foreign policy. It became clear that a new foreign policy strategy was not only needed, but was overdue.

Despite being a factor of the internal foreign policy environment, the 1999 Declaration on Foreign Policy also bears strong elements of the external domestic environment, namely a completely changed self-identification. In the Declaration, the previous identity-endangering elements of the geopolitical external foreign policy environment - in particular the geographical proximity to and historical context with the Balkans - were changed into opportunities, comparative advantages even, for foreign policy action. "Based on its geographical, political, economic, cultural and historical predispositions, Slovenia can withhold the stance of respect for international law, strive for respect of human rights at home and in the world and offer good offices in solving complicated situations both in its neighbourhood and elsewhere" (Declaration on Foreign Policy 1999: 8). Furthermore, the regional engagement of the state in Central and South 
Eastern Europe was to "strengthen the position of Slovenia within wider Euro-Atlantic politics" (Declaration on Foreign Policy 1999: 8). This 'new', holistic self-perception of the state was laid out in the 2002 government document in the context of engaging within Euro-Atlantic integrations, illustrating the Slovenian identity as Central European with a Mediterranean tradition and links with South-Eastern Europe, thus as "a bridge between different European regions" (Bojinović Fenko and Požgan 2014: 63).

From 1998 to 2004, the EU and NATO accession negotiations strongly influenced the internal and external domestic foreign policy environment. Strong top-down Europeanization was present in process and substance terms: in foreign policy-making processes, the central formulation and implementation agency became the government office for European affairs. The latter consisted of bureaucrats, experts in particular fields of EU policies. It was led by the head of the Slovenian accession negotiations team (Kajnč 2009). The entire external domestic foreign policy environment of Slovenia was afterwards centred on the EuroAtlantic accession process. It was important to meet the Copenhagen criteria, to take up the challenge of conditionality and to address the issue of reintegration into the SEE. During that period, the biggest failure of the Slovenian political and judicial system (and the government), which turned out to be a foreign policy constraint, was the non-implementation of the rights of so-called 'erased' people. This was demanded by the European Commission in 1998 (Bojinović Fenko and Urlić 2015: 115-116). The European Court of Human Rights' decision from March 2014, which was adopted in favour of some 26,000 affected former citizens of the Socialist Federal Republic of Yugoslavia, ${ }^{14}$ officially confirmed the gap between the declared and the de facto level of implementation of the state's constitutive identity element — the norm of the respect for human rights. As for the EU-NATO accession talks, they consumed a lot of energy from Slovenian politicians, policy-makers and even academics, so a lot needed to be done. In some way, this was anticipated by the late President of Slovenia, Janez Drnovšek, who in 2003 opened up a series of discussions with various members of the public about the future of Slovenia (Pogovori o prihodnosti Slovenije 2003). Some of these thoughts found their way into the new strategic foreign policy document, to which we turn our attention in the final section.

14 For various reasons, they failed to obtain Slovenian citizenship within the deadline set by the Slovenian government. Consequently, they were stripped of all rights as residents of Slovenia (hence 'the erased'), forcing them to file for a status in former Yugoslav republics, whence most of them originally came. 


\section{Post-2004 foreign policy: from steering cruisers to rowing the boat (in rough waters)}

After the EU and NATO accession, Slovenia again found itself in a vacuum. All major foreign policy goals had been accomplished, but no political reflection on the future strategic orientation seemed in sight. This internal environment factor had some important ramifications for Slovenia. General orientations, such as development assistance and the advocacy of human rights - in particular, the rights of the child - were considered by the Ministry of Foreign Affairs as traditional international activities. But the non-existence of a strategic foreign policy long-term plan made way for ad hoc decisions which Šabič and Kajnč (2014) termed "projectbased foreign policy": newly defined short-term goals, adjusted to the needs of a 'consumer', and with very little added value for Slovenia. Such 'projects' were the OSCE Presidency (2005), the Presidency of the Council of the EU (2008) and the Presidency of the Council of Europe (2009).

In retrospect, by holding presidencies of these international organizations, especially the EU, Slovenia took upon itself the responsibility to steer big cruisers, even though it had no knowledge, no experience, nor even sufficient capacity to do so. The presidencies took place at a time when Slovenia did not even have a foreign policy strategy of its own, and therefore no sense of the direction it would want to take in international affairs. Most importantly, it had low leadership capabilities and weak public administration as elements of the internal environment, and a lack of public support, let alone interest within the external domestic environment and the constraints of the external foreign environment in the form of the low ambitions of a small and new (member) state.

Considering these limitations, Slovenia has done a pretty good job. Save for some criticisms, especially with regard to the running of the OSCE Presidency (Šabič 2012), the Slovenian government proved its ability to deliver responsible European leadership. The fact that Slovenia conducted the presidencies of these bodies without any major procedural flaws — no matter the approach, termed a "symbolic challenge" by Kajnč (2009) and "playing it safe" by Klemenčič (2007) — resonated well with European 
states (Klemenčič 2007; Lenarčič 2007; Jazbec 2008). The procedural adequacy also boosted the image of Slovenia as a 'star pupil' of the Big Bang EU enlargement in the external domestic and foreign environment. But there is one paradox that is often overlooked when scholars analyse Slovenian presidencies. The job was made easier to some extent, because each presiding country, notably a small one, more or less runs the ongoing presidency agendas, with relatively little space to make its own footprint. Slovenia was no exception, but it was able to find a niche of its own. That niche was the Western Balkans. The latter were assessed among other 2008 EU presidency priorities as in fact the only true Slovenian substantive choice and contribution (Kajnč 2009). Considering the fact that Slovenia pursued the 'away from the Balkans' policy not so long before that, and that Slovenia increasingly saw itself as a bridge builder towards the Western Balkans, this may be seen as quite a remarkable accomplishment.

But the years of stardom have long gone. With regard to Slovenia's internal foreign policy environment, current and possibly future challenges of its foreign policy are based on a highly volatile state of affairs. Some challenges are due to the external foreign environment, mostly the global economic and financial crisis, whereas others have a different origin. We firstly shed light on the latter. As already mentioned, some of the (perpetual) constraints for foreign policy-making in Slovenia originate from low human resources-related capabilities when compared with other states, as was clearly seen in the unsuccessful bid for a non-permanent seat on the UN Security Council (2011), foreign policy mistakes from the past (in particular the lost cases at the European Court of Human Rights on the 'erased' and the Ljubljanska banka bank) and Yugoslav succession-related open issues, most notably the border dispute with Croatia (Bojinović Fenko and Šabič 2014). Highly relevant internal environment constraints were so-called personalized foreign policy orientations, which were made possible due to the absence of a codified foreign policy strategy. Examples of personalized foreign policy agendas would include economic diplomacy by Dimitrij Rupel (2004-2008) and environmental diplomacy by Samuel Žbogar (2008-2011). Along these lines, one could place the failed candidacy by former Slovenian Prime Minister Alenka Bratušek in October 2014 for EU Commissioner, responsible for energy union, and Vice-President of the Commission. Solo actions of some foreign policy officials have done little good to the standing of Slovenia as a credible partner. A good example 
is the statement by the Slovenian Minister of Foreign Affairs Karl Erjavec in 2015, in which he 'forecast' a result of the arbitration on the border dispute between Slovenia and Croatia, which he thought would be favourable to Slovenia (SiolNet 2015). The arbiters revealed their decision in June 2017: the debate about who 'won' and who 'lost' in this arbitration can go on forever. The incident which uncovered unprofessional conduct of the Slovenian arbiter and his aide, an employee in the Ministry of Foreign Affairs, can also be added to the list (MMCRTVSLO 2015).

Slovenia was hit particularly hard by the 2008 global economic and financial crisis, almost having accepted the troika. ${ }^{15}$ The previous romantic perception of the EU predominantly offering absolute gains to Slovenian society turned into a discussion about what EU policies should really be all about — that is to say, if Slovenia wanted to assure beneficial outcomes from EU policies, it could only do so through a much more active engagement in EU policy-making with regard to issues in its interest (Bojinović Fenko 2016). A warning was issued that the EU is not a system that would meet Slovenian values and national interests automatically, but might even jeopardize them (Lovec 2012). We evaluate this turn as a positive one per se. The public and the government became aware of the need to work much more substantively on European (and wider) foreign policy goals and analyse ex ante potential negative effects of international cooperation. Solidarity and equality, for example, had been reiterated as fundamental values after the Slovenian-and some governments of other EU member states - sensed that they were in an unequal position among Eurozone states as to how the Greek bailout had been handled, especially with regard to individual responsibilities (Bojinović Fenko and Svetličič 2017). This extends more generally into the domestic external environment, as national policy-makers are now being much more directly scrutinized with respect to meeting principles of democratic governance (in terms of responsibility of individual politicians and transparency of decision-making processes), especially with regard to management of state-owned companies, implementation of anticorruption measures, rule of law and fiscal sustainability. The economic crisis thus had a huge impact on the functioning of the domestic political

15 Slovenia had to resolve economic and fiscal problems and, during the period from April to June 2013, was seriously threatened by the European Commission that, should it not be able to resolve the issue of its budgetary imbalance on its own, it would to have to accept the intervention of the International Monetary Fund, the European Central Bank and the European Commission (the troika) (Bojinović Fenko and Svetličič 2017). 
system due to its high dependence on EU policy-making and policies. The uncertainties brought about by the crisis led to domestic political changes in mid-2014 in Slovenia. Early parliamentary elections and the emergence of an entirely new political party took place, ${ }^{16}$ a party whose platform was based on the value of rule of law, transparent and responsible policymaking, and clean slate politicians to lead the government coalition.

These circumstances in the external domestic environment helped create a political climate in favour of writing a new foreign policy strategic document. Between the 1999 Declaration on Foreign Policy and 2015, the only clear Slovenian foreign policy document addressed the Western Balkans. ${ }^{17}$ The process of codifying a new foreign policy strategy, headed by diplomat turned ambassador to the Czech Republic, Leon Marc, responded to the increasing public impatience with the government. Never before had a foreign policy document been so open to public debate as this draft foreign policy strategy. In countless sessions-many of them open to the interested public_foreign policy planners received rich material to work with, with plenty of new ideas and thoughts that eventually made it into the final text. The document was adopted in 2015 (Foreign Policy Strategic Document 2015). What seems of particular importance is that the writers were very much aware of how closely interlinked domestic and foreign affairs are in a country's life; in fact, there is even one sub-chapter devoted solely to explaining the interdependence between domestic and foreign affairs (Foreign Policy Strategic Document 2015: Chapter 1.3). According to Breuning's conceptualization of Ministries of Foreign Affairs (MFAs) as insulated and embedded agencies, the Slovenian MFA used to be a highly insulated agency (Bojinović Fenko and Šabič 2014: 51). However, the preparation of this strategic document strongly reflects a change in this respect and outlines the building of a "culture of foreign policy" (Foreign Policy Strategic Document 2015: 9-10). This potentially led to making the MFA an embedded agency within the political system, functioning via the transparent rules and organizational practices of other public institutions. In this vein, the MFA organized in 2016 and 2017 a range of expert debates (which included scholars, members of think tanks and the business community) on Slovenian future engagement in the EU and

16 The party was named Stranka Mira Cerarja (SMC: The Party of Miro Cerar) after its president, a professor of international constitutional law and previous former legal advisor to several Slovenian governments. In early 2015, the party renamed itself Stranka modernega centra (SMC: The Party of the Modern Centre).

17 The National Assembly in 2010 adopted a strategic document on the Western Balkans, which has ever since been operationalized in yearly action plans by the MFA. 
other international organizations. ${ }^{18}$ Additionally, in 2015 the MFA renewed its practices of recruiting new diplomatic staff, which has since been run via an open call for ten junior diplomats a year on profession-specific and entirely meritocratic selection criteria. ${ }^{19}$

With respect to the external foreign environment, the international political context, from the perspective of the developed North in general and Europe in particular, has drastically changed. Besides conventional threats that European countries, like any others, face today (international terrorism, ethnic conflicts, disrespect of international law), Slovenia's 2015 document made a specific reference to the rise of populism, as well as to the challenge of illegal migration and refugees. It clearly emphasized the dire consequences Europe (and, of course, Slovenia) might face if the ill response to outside challenges were to result, internally, in reducing some important rights such as free movement of labour within the EU, and, externally, in severe weakening of the EU as a global actor (Foreign Policy Strategic Document 2015: 6). The migration crisis of 2015-2016 triggered a set of challenges that may have a considerable impact on Slovenia with regard to its neighbourhood and beyond. The cooperation with Balkan countries during the migration crisis has proved to be not only a value but also a (functional) necessity. The management and eventual closure of the so-called Balkan route ${ }^{20}$ would have been impossible without the cooperation of critical countries such as Serbia and Macedonia. Yet, at the same time, of all its neighbours, Slovenia has the tensest relations with Croatia, a country which is a critical player in efforts to sustain stability in the Balkans. The prospect of good relations with other neighbours in lieu of decision-making and policy-making at the EU level is also not good. Hungary has fenced itself off, ostensibly because of the refugee threat. Austria insists on an indefinite 'temporary' measure to check the flow of passengers on its border with Slovenia, a Schengen state. Italy, on the other hand, continues to be a popular entry point for migrants. Slovenian Prime Minister Cerar reacted to these developments in February 2015 when, during the EU mini summit, he voiced strong criticism of the EU's

18 It is worth mentioning that Slovenian expert public opinion is gradually being liberated from academia and politics in the form of independent think tanks (e.g. Institute for Strategic Solutions formed in 2011 or Think Europe founded in 2016).

19 This withdrawal from previous occasional or sometimes prevailing exceptionalism in the recruitment and advancement practices of MFA (party links, nepotism, etc.) was ironically ended with the help of the economic crisis, which levelled the austerity measures in all ministries. On the effect of crisis on capital-based Slovenian experts in the Council of the EU working groups, see Bojinović Fenko and Lovec (2015).

20 Before its closure, this route was very popular with refugees and migrants who tried to make their way to the West. 
handling of the migration crisis and the potential of its mismanagement to tear apart the EU: "If we don't find a solution today, if we don't do everything we can today, then it is the end of the European Union as such" (World Post 2015). In January 2016, he additionally called for a joint European solution, including common EU measures and external border management, in his letter to the leaders of the EU and the countries along the Balkan migration route. ${ }^{21}$ Beside the traditional external foreign environment challenges (e.g. being a small state), foreign policies of neighbouring states and states of Central and Eastern Europe more widely, coupled with the inability of the EU to conduct resolute and consistent policy promises on migration management, have recently become a big constraint for Slovenia.

\section{Conclusion}

Foreign policy decisions taken by Slovenia during the period 1975-1992 can be explained via the interplay of all foreign policy environments. The internal environment at the very end of this pre-recognition period was an important constraint, but was neutralized via paradiplomatic activities. As a former Yugoslav republic with limited means of foreign representation, Slovenia had to rely on individuals from the Yugoslav diplomacy and, from the late 1980s onwards, extensively on non-governmental organizations, most notably social and political organizations, academia and companies doing business abroad. Domestic and international legitimacy were being pursued via the prioritization of democratic norms, especially the rule of law and the respect for international law in domestic and foreign policy. The foreign policy system and external domestic environment were being quickly built while benefiting from positive historical and political geography (e.g. valuable experience of doing business with the West). The internal and domestic external environments were built systematically to make the necessary change from the constraints of state formation to opportunities for domestic and foreign policy action. Of course, it was the change in the external foreign environment — the fall of the Socialist 
Federal Republic of Yugoslavia and the growing support in the West for democratization in former Communist countries via reinterpretation of principles of international law - that represented a great opportunity to implement plans for independence and eventually international recognition.

In the second period (1992-2004), the main foreign policy constraint was the geopolitical and historical proximity to the war-waging former Yugoslav republics as the external domestic environment, which posed a threat to Slovenia's effort to create an image of a democratic, rule of (international) law respecting state. The external foreign environment again offered opportunities for action, albeit not necessarily always in Slovenia's favour. Firstly, the chances for Slovenia to become a member of Euro-Atlantic organizations became linked with the political condition to replace its 'away from the Balkans' policy with a more proactive approach towards the region. Secondly, persistent pressure from European institutions - most notably the EU - was being put on Slovenia with reference to the state systemic transition to democracy and a market economy (the shape of the external domestic environment). During that period, Slovenian decision-makers learned that effective implementation of conditions set by foreign bilateral or multilateral authorities was valued not only in de facto progress to membership status but also in the continuous positive perception of Slovenia as the so called 'star pupil'. However, this enormous non-critical obedience to the foreign environment also led to mistakes. These mistakes proved huge constraints for Slovenian foreign policy (e.g. lost court cases before the ECHR on the 'erased' and the Ljubljanska banka, other open succession issues including arbitration on the border with Croatia, and an ambiguous attitude towards the NAM). If the international community did not put pressure on Slovenia to conform to certain commonly accepted policies or laws, the internal and external domestic environments would not have the capabilities (or will) to identify some major problems with the non-implementation of respect for human rights and the rule of (international) law, the very principles on which Slovenian identity is built. With regard to this period, we conclude that the foreign external environment represented itself as an opportunity to be taken, but the internal and external domestic environments became a decisive long-term constraint. 
As for the post-2004 period, after NATO and EU accession, Slovenia suffered 'foreign policy fatigue' in the internal environment. The 1999 strategy, focusing primarily on achieving membership of NATO and the EU, was, with the exception of the Western Balkans and the bridge-building agenda, obsolete. Yet no document followed it. The vacuum was filled by occasional appearances in the role of holders of presidencies of international organizations. Because the Slovenialed presidencies were, by general acclaim, done well, once again the external foreign environment strengthened the image of the foreign policy of a successful state. The main constraint was primarily in the internal environment. Slovenian governments one after the other failed to provide a comprehensive reflection of Slovenia's place and direction in the world. Some ministers of foreign affairs used that 'empty space' to their own advantage and ran personalized foreign policy agendas. These constraints, however, are addressed in the new foreign policy strategy which Slovenia adopted in 2015. Other challenges to Slovenian foreign policy were seen, especially in the global economic and financial crisis. Paradoxically, the very environment which the state previously uncritically praised (advantages and opportunities of being a member of the EU) now pushed the decision-makers and the public to renew their self-identification and perception of EU integration. The migration crisis brought about more solo foreign policies of neighbouring states and states of wider Central and Eastern Europe, coupled with the inability of the EU to conduct resolute and consistent policy promises on migration management. This leads us to the (worrying) conclusion that the external foreign environment, which up to now has offered most opportunities for Slovenian foreign policy action, has recently become a big constraint. This can help explain why Slovenia has reacted rather ambiguously to the migration crisis by appealing to strengthening this foreign environment via common action but at the same time refraining from its own highly self-praised human rights advocacy, moving instead to securitizing the migrant issue in domestic legislation, and, ironically, to rely more on the Western Balkans. 


\section{Bibliography}

Boeckh, K., 2014. Allies are forever (until they are no more): Yugoslavia's multivectoral foreign policy. In: Keil, S. and Stahl, B. eds. The foreign policies of post-Yugoslav states: from Yugoslavia to Europe. Basingstoke and New York: Palgrave Macmillan. pp. 18-43.

Bojinović, A., 2005. Geographical proximity and historical context as a basis of active foreign policy strategy of small European states: the case of Austria and Slovenia regarding the western Balkans. Politics in Central Europe, 1(1): 8-29.

Bojinović Fenko, A., 2010. The Balkans as a part of the Mediterranean region: political-historical contextualisation of the recent shift in regional governmental relations. Journal of Comparative Politics, 3(1): 70-100.

Bojinović Fenko, A., 2014. Foreign policy change in new states: a comparative foreign policy analysis of post-Yugoslav states. In: Lovec, M., ed. Lessons learned for the European Union: a reflection on stronger co-operation in the Western Balkans for a better European future. Ljubljana: Faculty of Social Sciences. pp. 17-29.

Bojinović Fenko, A., 2016. Slovenia: learning of (self-)governance in the conditions of Europeanisation. In: Pertusot, V. ed. The European Union in the fog: building bridges between national perspectives on the European Union: final report of the project 'Building Bridges between National Perspectives on the European Union'. Paris: Institut Français des Relations Internationales, pp. 201-210, [pdf]. Available at: https://www.ifri.org/sites/default/ files/atoms/ files/the_european_union_in_the_fog-1_1_0.pdf (Accessed 29 September 2017).

Bojinović Fenko, A. and Lovec, M., 2015. From a good to a poor student: the de-Europeanization of Slovenian foreign policy in the light of (European) economic and financial crisis. Etudes Helléniques, 23(1): $111-140$. 
Bojinović Fenko, A. and Požgan, J., 2014. Regionalisation of Slovenian foreign policy: escape from the Balkans, return to the Western Balkans. Studia Historica Slovenica, 14(1): 55-74.

Bojinović Fenko, A. and Šabič, Z., 2014. From the Balkans to Central Europe and back: foreign policy of Slovenia. In: Keil, S. and Stahl, B. eds. The foreign policies of post-Yugoslav states: from Yugoslavia to Europe. Basingstoke and New York: Palgrave Macmillan. pp. 47-68.

Bojinović Fenko, A. and Svetličič, M., 2017. Slovenia and the European Union. Oxford research encyclopaedia of politics, [online]. Available at: http://politics.oxfordre.com/ view/10.1093/ acrefore/9780190228637.001.0001/acrefore-9780190228637-e-509 (Accessed 20 July 2017).

Bojinović Fenko, A. and Urlić, A., 2015. Political criteria vs. political conditionality: comparative analysis of Slovenian and Croatian European union accession processes. Croatian International Relations Review, 21 (72): 107-137.

Brglez, M., 1996. Diplomatic relations, modern law of diplomacy and the Republic of Slovenia. Selected aspects. Journal of International Relations and Development, 3(1-4): 54-63.

Bučar, B., 1994. Slovenska zunanja politika med Evropo in Balkanom. Teorija in Praksa, 31 (11-12): 1063-1068.

Bučar, B., 1995. Slovenia. In: Neuhold, H., Havlik, P. and Suppan, A. eds. Political and economic transformation in East Central Europe. Boulder, San Francisco, Oxford: Westview Press. pp. 281-93.

Bučar, F., 2014. Dynamics and dialectics of the emergence of Slovene state and its diplomacy. In: Jazbec, M. ed. Sociology of diplomacy: initial readings. Istanbul: Istanbul Kültür University, pp.197-215.

Carlsnaes, W., 2012. Actors, structures and foreign policy analysis. In: Smith, S., Hadfield, A. and Dunne, T. eds. Foreign policy: theories, actors, cases. 2nd ed. Oxford: Oxford University Press. pp. 113-129.

Commission, 1997. Commission's opinion on Bulgaria's application for membership in the European Union, Doc. 97/11. Brussels, 15 July [pdf]. Available at: http://www.esiweb.org/pdf/bulgaria_EC- 
opinion\%20on\%20BG\%20application_1997.pdf (Accessed 18 July 2017).

Constitution of Slovenia, 2006. Ustava Republike Slovenije. Uradni list Republike Slovenije no. 68/06, 30 June 2006, [pdf]. Available at: http://www.us-rs.si/media/ustava. republike.slovenije.pdf (Accessed 15 March 2015).

Constitution of the Socialist Federative Republic of Yugoslavia, 1974. Constitution of the Socialist Federative Republic of Yugoslavia, endorsed 21 February 1974. In: Ustava Socialistične federativne republike Jugoslavije. Ljubljana: Dopisna Delavska Univerza.

Declaration on Foreign Policy, 1999. Deklaracija o zunanji politiki Republike Slovenije. Endorsed by the Parliament of the Republic of Slovenia 17 December 1999, [online]. Available at: http://www.pisrs.si/Pis. web/pregledPredpisa?id=DEKL3 (Accessed 29 September 2017).

Duran, M., 2016. Paradiplomacy as a diplomatic broker; between separating differences and engaging commonalities. Diplomacy and Foreign Policy, 1 (3): 1-56.

Foreign Policy Strategic Document, 2015. Slovenija: varna, uspešna in v svetu spoštovana. Zunanja politika Republike Slovenije. Ministry of Foreign Affairs of the Republic of Slovenia, [pdf]. Available at: http:// Www.mzz.gov.si/fileadmin/pageuploads/foto/1507/STRATESKI_ DOKUMENT_-_KONCNO_-_PDF.pdf (Accessed 28 April 2017).

Government Bureau of Communication, 2015. International recognitions of Slovenia. [online]. Available at: http://www.dvajset.si/prvih-20/ pregled/prej-in-zdaj/mednarodna-priznanja/ (Accessed 29 September 2017).

Hey, J. A. K., 2003. Small states in world politics: explaining foreign policy behaviour. Boulder, London: Lynne Rienner.

Hill, C., 2003. The changing politics of foreign policy. Houndmills, Basingstoke and Hampshire: Palgrave Macmillan.

Hill, C., 2016. Foreign policy in the twenty-first century. 2nd ed. Houndmills, Basingstoke and Hampshire: Palgrave Macmillan.

Hudson, V. M., 2014. Foreign policy analysis: classic and contemporary 
theory. 2nd ed. Maryland, ZDA: Rowman in Littlefield Publishers.

Jazbec, M., 2008. Slovenian EU presidency: a first class diplomatic endeavour. In: Jazbec, M. ed. Slovenia's presidency of the Council of the European Union: external relations. Ljubljana, Slovenia: Ministry of Foreign Affairs. pp. 111-115.

Jazbec, M., 2011. Pomen in prihodnost paradiplomacije: Slovenija (izhodišča za šłudijo primera). In: Udovič, B., Brglez, M., Rupel, D., Simoniti, I., Jazbec, M., Kunič, J., Avguštin, J. R., Žigon, Z., Bergelj, N., Smole, M. and Brozina, D. eds. Diplomacija med teorijo in prakso. Ljubljana, Slovenija: Fakulteta za družbene vede. pp. 101-124.

Jazbec, M., 2012. Po Koroškem, po Kranjskem: ali kako je nastajala slovenska država in njena diplomacija. [online]. Available at: http://www.mzz.gov.si/si/20_obletnica_mednarodnega_priznanja_ republike_slovenije/spomini_slovenskih_diplomatov/dr_milan_ jazbec/ (Accessed 29 September 2017).

Kajnč, S., 2009. The Slovenian presidency: meeting symbolic and substantive challenges. JCMS, 47(Annual Review): 89-98.

Kajnč, S., 2011. Slovenia: searching for a foreign policy identity via the EU. In: Wong, R. and Hill, C. eds. National and European foreign policies. Oxon and New York: Routledge. pp. 189-209.

Kinsella, D. T., Russett, B. M. and Starr, H., 2013. World politics: the menu for choice. 10th ed. Boston: Wadsworth, Cengage Learning.

Klabjan, B., 2013. Transnacionalne politike, nacionalna diplomacija: Slovenci in Delovna skupnost Alpe-Jadran, 1978-1991. Acta Histriae, 21/3: 409-426.

Klemenčič, M., 2007. A star pupil playing it safe in the EU: an inside view of the first Slovenian EU Council presidency. Notre Europe, [pdf]. Available at: http://www.notre-europe.eu/media/etud61mklemencic-slovenianpresidency-en.pdf?pdf=ok (Accessed 29 September 2017).

Lenarčič, J., 2007. Slovenian presidency to "add value" to existing EU policies. Euractiv, 17 December, [online]. Available at: http://www. euractiv.com/future-eu/lenari-slovenian-presidency-add-value- 
existing-eu-policies/article-169110 (Accessed 29 September 2017).

Lovec, M., 2012. The European Union is no free lunch: reconsidering the eastern enlargement of the EU from an intergovernmental perspective. Croatian International Relations Review, 17(66): 31-58.

MMCRTVSLO, 2015. Erjavec: če so posnetki resnični, je najhujša možna posledica izločitev sodnika. [online]. Available at: https://www. rtvslo.si/slovenija/erjavec-ce-so-posnetki-resnicni-je-najhujsamozna-posledica-izlocitev-sodnika/370179 (Accessed 29 April 2017).

Pogovori o Prihodnosti Slovenije, 2003. Pogovori o prihodnosti Slovenije pri Predsedniku Republike. [online]. Available at: http://www. prihodnost-slovenije.si/uprs/ps.nsf/krz/ 49331EE5228652FAC1257142 004982D2? OpenDocument (Accessed 1 May 2017).

Rahten, A., 2011. Očrt slovenske diplomacije ali diplomacije Slovencev. Teorija in praksa, 48(3): 646-667.

Roberts, I., 2016. Conversations with Milošević. Athens: The University of Georgia Press.

Rupel, D., 1996. Slovenia's shift from the Balkans to Central Europe. In: Benderly, J. and Craft, E. eds. Independent Slovenia. New York: St Martin's Press. pp. 183-200.

Rupel, D., Trekman, B., Jazbec, M. and Golob, I., 2000. Deset let samostojne slovenske zunanje politike. [pdf]. Available at: http://www.mzz. gov.si/fileadmin/pageuploads/Zakonodaja_in_dokumenti/ dokumenti/10_let_samostojne_slovenske_zunanje_politike.pdf (Accessed 26 April 2017).

Russett, B. and Starr, H., 1981/1996. World politics: the menu for choice. San Francisco, CA: W. H. Freeman.

Šabič, Z., 2002. Slovenia and the European Union: a different kind of twolevel game. In: Linden, R. ed. Norms and nannies: the impact of international organizations on the Central and East European States. Lanham: Rowman \& Littlefield. pp. 91-127.

Šabič, Z., 2012. Pogled v prihodnost ob oziranju v preteklost: Slovenska zunanja politika po letu 2011. In: Prunk, J. and Deželan, T. eds. 
Dvajset let slovenske države. Maribor: Aristej. pp. 113-138.

Šabič, Z. and Bunič, P., 2013. The Europeanization of Slovenian foreign policy: a one-way process? In: Baun, M. J., and Marek, D. eds. The new member states and the European Union: foreign policy and Europeanization. London and New York: Routledge. pp. 85-98.

Šabič, Z. and Kajnč, S., 2014. Past, present and future: Slovenia, European institutions and the problem of project-based foreign policy. Studia Historica Slovenica, 14(1): 37-54.

SiolNet, 2015. Arbitražno sodišče opozorilo Karla Erjavca zaradi neprimernih izjav. [online]. Available at: http://siol.net/novice/slovenija/ arbitrazno-sodisce-opozorilo-karla-erjavca-zaradi-neprimernihizjav-412927 (Accessed 29 April 2017).

Slovenian Foreign Policy Strategy, 1991. Temelji strategije zunanje politike Republike Slovenije. Poročevalec Skupščine Republike Slovenije, 10, 26 March. pp.11-15.

Udovič, B. and Brglez, M., 2011. Slovenske diplomatske študije med diplomatsko prakso in teorijo. In: Udovič, B., Bojinović Fenko, A., Svetličić, M. eds. Diplomacija med teorijo in prakso. Ljubljana: Založba FDV. pp. 11-47.

Vlada Republike Slovenije, 2016. Letter by Miroslav Cerar. Press release, 18 January [pdf]. Available at: http://www.vlada.si/fileadmin/ dokumenti/si/Sporocila_za_javnost/2016/Pismo_PV_jan_2016-finaleng.pdf.

World Post, 2015. Slovenia warns of EU collapse under strain of refugee crisis. [online]. Available at: http://www.huffingtonpost.com/ entry/slovenia-warns-of-eu-collapse-under-strain-of-refugee-crisis_ us_562d2e76e4b0aac0b8fd36b4 (Accessed 28 April 2017).

Ana Bojinović Fenko (ana.bojinovic@fdv.uni-lj.si) is an Associate Professor of International Relations at the University of Ljubljana, Faculty of Social Sciences. She publishes in the field of international (inter-)regionalism with a focus on the 
Mediterranean region, in the field of (comparative) analysis of foreign policy with a focus on Slovenia and other postYugoslav states and on the issues of European Union external action, specifically, the enlargement to the Western Balkans and EU Mediterranean policy. She is Head of the International Relations Chair at the above mentioned Faculty and is engaged in teaching at study programmes International Relations and European Studies. She holds a Jean Monnet Module 2016-2019 EU Environmental Policy: Internal and external dimensions (EUenvi). Since 2015, she is co-editor of the International Journal of Euro-Mediterranean Studies IJEMS (http://www.emuni.si/en/ijems).

Zlatko Šabič (zlatko.sabic@fdv.uni-lj.si) is a Professor of International Relations at the University of Ljubljana, Faculty of Social Sciences. He publishes in the fields of international relations, international organisations, international parliamentary relations and diplomacy, European integration, Central and Eastern Europe, and the Western Balkans. His most recent book project was on "International Relations in Central Europe" (co-edited with Petr Drulák and published by Palgrave in 2012). Professor Šabič was the President of the Central and East European International Studies Association (CEEISA) from 2006 to 2010. He was a member of the Steering Committee of the Standing Group of International Relations within the ECPR (2010-2013) and is one of the founders of the European International Studies Association, the largest network of international relations professionals in Europe (http://www.eisa-net.org/) where he also served one term as the member of the Board (2013-2015). 